\title{
Reflexives in Czech from a dependency perspective
}

\author{
Václava Kettnerová \\ Charles University \\ Faculty of Mathematics and Physics \\ Prague, Czech Republic \\ kettnerova@ufal.mff.cuni.cz
}

\author{
Markéta Lopatková \\ Charles University \\ Faculty of Mathematics and Physics \\ Prague, Czech Republic \\ lopatkova@ufal.mff.cuni.cz
}

\begin{abstract}
Reflexives are the source of ambiguity in many languages, including Czech. In this paper, we address Czech reflexives and their description in the dependency-oriented theory, Functional Generative Description. Our primary focus in this paper lies in the reflexives that form analogous syntactic structures as personal pronouns (e.g., Jan si / jí nevěř́. 'John does not believe in himself / in her.'). In Czech (similarly as in other Slavic languages), these reflexives encode reflexivity or reciprocity, two closely related phenomena. We offer an in-depth analysis of both these phenomena and propose their description in lexicon and in grammar. Further, we clarify principles underlying ambiguity of reflexive and reciprocal constructions.
\end{abstract}

\section{Introduction}

Reflexives appear in a great number of languages. Due to an enormous diversity in their functions, their description represents a tricky task for any syntactic theory. A large number of analyses of reflexives apply methodological principles of a generative syntax, see esp. (Chomsky, 1981; Reinhart and Reuland, 1993; Pollard and Sag, 1992), usually making an effort to provide their unified analysis. Recently, reflexives have been studied in individual languages as well as from a typological perspective, attesting their high ambiguity across languages, see esp. (Faltz, 1985; Geniušienė, 1987; Kemmer, 1993; Frajzyngier and Walker, 2000a; Frajzyngier and Walker, 2000b; König and Kokutani, 2006; Nedjalkov, 2007; König and Gast, 2008; Evans et al., 2011). In this paper, we provide a description of various functions of reflexives in Czech and propose their representation in a dependency-oriented theory, namely in the Functional Generative Description (FGD henceforth) (Sgall et al., 1986; Panevová et al., 2014), with an emphasis put on the distribution of the linguistic information between lexicon and grammar, as two sides of the language description.

In Czech linguistics, reflexives are classified either as a part of verb lemmas or inflectional verb forms, or as the reflexive pronoun. The primary focus in this paper lies in the reflexives representing the reflexive pronoun occurring in reflexive and reciprocal constructions. We offer an in-depth analysis of the deep and surface syntactic structures of these constructions - in FGD, the former one roughly corresponding to the so-called tectogrammatical layer, i.e., a layer of the linguistically structured meaning, while the latter is represented by the so-called analytical layer, see esp. (Sgall et al., 1986; Hajič et al., 2018). We thus provide a comprehensive account of these two related phenomena in verbal as well as nonverbal structures, which allows for generation of well-formed reflexive and reciprocal constructions. We follow and further deepen analysis of the description proposed in (Kettnerová and Lopatková, 2018b; Kettnerová and Lopatková, 2018a) putting under scrutiny other parts of speech than verbs as well.

\section{Reflexives in the Functional Generative Description}

While the classification of the long forms of the reflexive sebe/sober/sebou as the reflexive pronoun does not pose any difficulties in Czech linguistics, the status of the reflexive clitics se/si is rather questionable. Their analysis is heavily dependent on the overall architecture of a linguistic theory within which it is conducted, see esp. (Karlík, 1999; Oliva, 2001; Medová, 2009; Veselý, 2018). In FGD, reflexives are classified according to their function in the language system, i.e., functionally equivalent reflexives take 
the identical status in the language description, regardless of their clitic or long forms, see esp. (Panevová, 2001; Panevová et al., 2014; Kettnerová et al., 2014). On the basis of their function, reflexives are distinguished into the reflexive pronoun and into the reflexives representing either parts of verb lemmas (often referred to as inherently or derived reflexive verbs, see below), or reflexive inflectional verb forms.

Reflexive Pronoun. In Czech, the reflexive pronoun has the long forms sebe/sobělsebou or the clitic forms $s e / s i$; the clitic forms are available only in the prepositionless accusative case ( $s e$ ) and in the dative case $(s i)$. Only those reflexive clitics are treated as the reflexive pronoun that can change - depending on their position in a sentence - into long forms when stressed, see also (Komárek et al., 1986). The reflexive pronoun - similarly as non-reflexive pronouns - fills one valency position of a predicate (a verb, a noun, an adjective or an adverb). In Czech, the reflexive pronoun, marking the referential identity between the filled position and another expression, encodes reflexivity (Section 3) or reciprocity (Section 4).

In examples with the verb verrit 'to believe' (2), PAT of the verb, see the valency frame in (1), is filled with the reflexive pronoun in the clitic form (2a) or in the long form (2b), respectively, coreferring with Jan 'John' in the subject position given by ACT of the verb; in both variants the reflexive encodes reflexivity. Similarly, in examples (3) with the same verb, the reflexive pronoun in the clitic and long form, filling PAT, corefers with ACT of the verb; depending on the context, the reflexive pronoun marks either reflexivity, or reciprocity, see Figure 1a below.

(1) verrit impf 'to believe': $\mathrm{ACT}_{1} \mathrm{PAT}_{3, \mathrm{dcc}} 1$

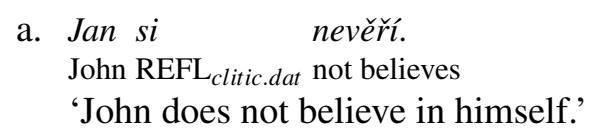

b. Jan nevěř sobě, věř ale manželce. John not believes $\mathrm{REFL}_{\text {long.dat }}$, believes but wife 'John does not believe in himself but he believes in his wife.'

(3) a. Lidé ve městěsi neveř̌í. people in town REFL $_{\text {clitic.dat }}$ not believe 'People in towns do not believe in themselves // in each other.'

b. Lidé ve městě sobě nevěř́. people in town $\mathrm{REFL}_{\text {long.dat }}$ not believe 'People in towns do not believe in themselves // in each other.'

Reflexives in Verb Lemmas. As parts of verb lemmas, only the clitic reflexives se and si occur (as such they cannot be stressed and they do not fill valency position of a verb). These clitic reflexives appear with reflexive tantum verbs (referred also to as inherently reflexive verbs), see example (4a) with the reflexive se as an obligatory part of the verb lemma blizit se 'to approach' and (4b) with si belonging to the verb lemma odpočinout si 'to rest' (Figure 1b). Further, the clitic reflexives serve as derivational means, deriving reflexive verbs (referred also to as derived reflexive verbs) from irreflexive ones; the derivational process can have various semantic and/or syntactic motivations, ${ }^{2}$ see examples with the verb budit 'to wake' (5a) and with the derived verb budit se 'to wake' (5b) (with the reflexive se marking decausativity) and examples with the verb pomáhat 'to help' (6a) and the derived verb pomáhat si 'to help' (6b) (with the reflexive si signaling inherent reciprocal meaning). ${ }^{3}$

\footnotetext{
${ }^{1}$ In valency frames, numbers stand for morphemic cases $(1=$ nom, $2=$ gen, $3=$ dat, $4=$ acc, $6=10 c, 7=$ instr $)$, possibly preceded by required prepositions, dcc stands for dependent content clauses (often referred to as nominal subordinate clauses), and pos represents possessive forms. As it is not relevant for our explanation here, we omit the information on obligatoriness from valency frames.

${ }^{2} \mathrm{~A}$ detailed analysis of semantic and syntactic functions of the clitic reflexives se/si that serve as derivational means, providing an account for a possible difference in the distribution of these two clitics, has not been done for Czech yet. However, such an analysis goes beyond the scope of this paper; from the reflexives representing parts of verb lemmas, only the reflexives in lemmas of inherent reciprocal predicates are considered here in connection with reciprocity, see example (6b) and Section 4.

${ }^{3}$ The clitic reflexives se and si occur also with the verbal nouns and present participles of verbs that are systematically derived by productive suffixes from verbs with reflexive lemmas; while with the present participles, the clitics are obligatory,
} 

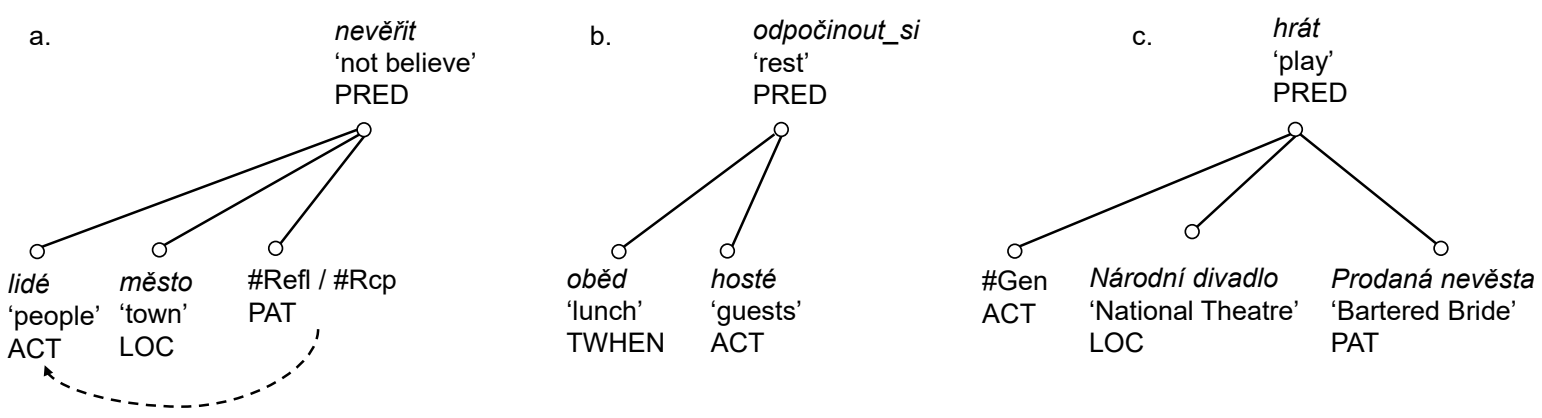

Figure 1: The simplified tectogrammatical trees of sentences (3), (4b) and (7a), respectively. In tree (a), the dashed arrow indicates coreference, pointing from the reflexive pronoun to its antecedent; as ambiguous structures must be distinguished at the tectogramatical layer, this scheme represents - for the sake of brevity - two trees: one with the \#Refl lemma and the other with \#Rcp lemma, both standing for the reflexive pronoun, distinguishing its function. In tree (b), the reflexive is represented as the part of the verb lemma. In tree (c), the reflexive inflectional verb form is derived on the basis of grammatical rules conditioned by the value of the verbal grammateme 'deagentive' (not displayed), resulting in generalization of ACT (the lemma \#Gen). For the annotation principles see esp. (Mikulová et al., 2006).

(4) a. Horolezci se /*sebe bližili kvrcholuhory.

mountaineers $\mathrm{REFL}_{\text {clitic }} / \mathrm{REFL}_{\text {long }}$ approached to summit of mountain

'Mountaineers were approaching to the summit of the mountain.'

b. Po obědě si /*sobě hosté odpočinuli.

after lunch $\mathrm{REFL}_{\text {clitic }} / \mathrm{REFL}_{\text {long }}$ guests rested

'The guests had a rest after the lunch.'

(5) a. Maminka budila děti v sedm hodin.

'Mother woke children up at seven o'clock.'

b. Děti se / *sebe budilyvsedmhodin.

children $\mathrm{REFL}_{\text {clitic }} / \mathrm{REFL}_{\text {long }}$ woke at seven o'clock

'Children woke up at seven o'clock.'

(6) a. Jan pomáhal kolegům při práci.

'John helped his colleagues at work.'

b. Jan si / *sobě při práci pomáhal s kolegy.

John $\mathrm{REFL}_{\text {clitic }} / \mathrm{REFL}_{\text {long }}$ at work helped with colleagues

'John and colleagues helped at work with each other.'

As for the representation of the clitic reflexives of the given type, they are recorded in the lexicon as parts of relevant lemmas.

Reflexives in Inflectional Verb Forms. With verbs, the clitic reflexive se can represent also a part of the reflexive verb form, which is characteristic of marked constructions of the deagentive and dispositional diatheses (also referred to as middle alternation), see examples (7a) and (7b), respectively. In this case, the clitic reflexive se serves as a voice marker, being thus an inflectional means; as such this reflexive does not occupy a valency position of a verb and it cannot be stressed.

The inflectional reflexive verb form brings about a shift of ACT of a verb from the subject position: in case of the deagentive diathesis, the ACT is elided from the surface (7a), see Figure 1c, and in case of the dispositional diatesis, it can be optionally expressed in the dative case ( $7 b)$.

e.g., bojicí se 'having fear' ( $\leftarrow$ bát se 'to fear') and stěžujicí si 'complaining' ( $\leftarrow$ stěžovat si 'to complain'), with the verbal nouns, they are only optional, e.g. bání (se) 'fearing' and stě̌zování (si) 'complaining'. In both cases, the presence of the clitic reflexive is considered as evidence of the verbal character of these nouns and participles, see esp. (Dvořak, 2017). These forms are left aside here. 
a. V Národním divadle se / * *sebe hrála Prodaná nevěsta. in National Theatre $\mathrm{REFL}_{\text {clitic }} / \mathrm{REFL}_{\text {long }}$ played Bartered Bride 'The Bartered Bride was played in the National Theatre.'

b. Koláč se /*sebe (mamince) špatně pekl. pie $\mathrm{REFL}_{\text {clitic }} / \mathrm{REFL}_{\text {long }}$ (for mother) badly baked 'The pie baked badly (for my mother).

As for the representation of the deagentive and dispositional diatheses, syntactic changes in the surface structure of verbs can be captured by formal rules comprised in the grammar, while the applicability of these diatheses must be recorded in the lexicon as it is given by the lexical meaning of verbs to a great extent and as such it is not derivable from the valency structure of verbs itself.

\section{Reflexivity and Its Encoding in Czech}

Reflexivity represents language means expressing the fact that two semantic participants of a predicate have a single referent. In Czech linguistics, reflexivity has gained a lot of attention, see esp. (Havránek, 1928; Karlík, 1999; Dočekal, 2008; Medová, 2009; Hudousková, 2009). Within FGD, reflexivity has been studied esp. by Panevová (2001, 2008) and her discussion with Oliva and others (Oliva, 2000; Oliva, 2001; Komárek, 2001; Kettnerová et al., 2014).

In Czech, reflexivity can characterize verbs (8a), nouns (8b), adjectives (9a) and sporadically adverbs (9b) (reflexivity of adverbs are left aside here due to data sparseness). A substantial role in its expression is played by the reflexive pronoun. ${ }^{4}$

(8) a. Marie se pořád jen lituje.

'Mary feels sorry for herself all the time.'

b. Mariina lítost nad sebou

'Mary's sorrow for herself'

(9)

a. necitlivý $k$ sobě

'insensitive to herself/himself'

b. necitlivě $k$ sobě

'insensitively to herself/himself'

Reflexive constructions can be described as a result of a morphosyntactic operation of reflexivization applied to a valency frame of a predicate. As the applicability of this operation cannot be derived from the valency structure itself, it must be provided with each relevant predicate in the lexicon. However, morphosyntactic patterns underlying reflexivity are so regular that they can be captured in the form of rules contained in the grammar. These patterns are further described below.

Reflexivity in Deep Structures. In the deep syntactic structure of reflexive constructions, the number and type of valency complementations of a predicate are preserved. Moreover, the mapping between semantic participants and valency complemenations ${ }^{5}$ remains the same as in non-reflexive constructions, i.e, each semantic participant is mapped onto a single valency complementation. ${ }^{6}$ The main difference lies in the fact that in reflexive constructions, two semantic participants refer to a single referent; as a result, the valency complementations involved in reflexivity are linked by a coreferential relation.

\footnotetext{
${ }^{4}$ In the VALLEX lexicon, reflexivity is captured only with lexical units of verbs that allow the reflexive pronoun in prepositionless dative or accusative - counting only cases where reflexivity affects actants, it is annotated with 578 lexical units of verbs, represented by 690 verb lemmas (if relevant, one lexical unit is represented by lemmas of different aspectual values; moreover, lemmas can have ortographic variants, e.g., oblékat ${ }^{i m p f} /$ obléci/obléknout ${ }^{p f}$ 'to put on sth'). In PDT, reflexivity is annotated in 712 instances (only cases affecting actants are counted): 695 in verbal structures, 7 in nominal structures and 10 in adjectival structures, represented by 451 verb lemmas, 8 noun lemmas, and 6 adjective lemmas; however, out of these instances, 171 represent annotation errors: 49 instances are syntactic reciprocals, 16 are lexical reciprocals, 104 are rather reflexive verb lemmas, and 2 are inflectional reflexive verb forms.

${ }^{5}$ Roughly corresponding to semantic actants and deep syntactic actants, respectively, in the Meaning-Text Theory (Mel'čuk, 2004).

${ }^{6}$ Compare with the complex mapping of semantic participants in reciprocal constructions discussed in Section 4.
} 
Let us demonstrate the operation of reflexivization on the verb uctivat / uctit 'to respect' and the deverbal noun úcta 'respect'. Both these predicates evoke two semantic participants, 'Cognizer' and 'Evaluee', mapped in both cases onto ACT and PAT, respectively, see the valency frames in (10) and (12). The mapping remains the same regardless whether 'Cognizer' and 'Evaluee' refer to different referents or to a single referent; however, in the latter case, the deep syntactic structure of these predicates is characterized by coreference between ACT and PAT, see examples (11) and (13) and their simplified dependency trees in Figure $2 a$ and $2 b{ }^{7}$

Further, the adjective uctivy respectful, derived from the verb uctivat 'to respect', is characterized by the same set of semantic participants, Cognizer and Evaluee. However, from these participants, only the latter one can be syntactically structured as a valency complementation of the adjective; $;^{8}$ this participant is mapped onto PAT, see the valency frame in (14). The participant Cognizer is typically syntactically structured outside adjectival structures, either as the governor of the adjective (15a), or as ACT of the copula verbs být 'to be' and stávat se / stát se 'to become' with the adjective (15b), see esp. (Boguslavsky, 2003). As a consequence, the coreference relation links PAT of the adjective and either its governor, see Figure 2c, or ACT of copula verbs. ${ }^{9}$

$$
\text { uctívat impf / uctit }{ }^{p f} \text { 'to respect': } \mathrm{ACT}_{1} \mathrm{PAT}_{4, \mathrm{dcc}}
$$

a. Tarkovskij začal, tvrdí pisatel, nakonec sám sebe uctívat. Tarkovsky began, claims writer, finally alone $\mathrm{REFL}_{\text {long.acc }}$ respect 'As the writer claims, Tarkovskij finally began to honor himself.'
b. Tarkovskij se (sám) uctíval. Tarkovsky REFL clitic.acc $_{\text {(alone) respect }}$
'Tarkovskij honored himself.'

(12) úcta 'respect': $\mathrm{ACT}_{2, \mathrm{pos}} \mathrm{PAT}_{\mathrm{k}+3}$

(13) Tarkovského úcta $k$ sobě Tarkovsky's respect to REFL long.dat $_{\text {. }}$

'Tarkovsky's respect for himself'

$$
\begin{aligned}
& \text { uctivý 'respectful': } \mathrm{PAT}_{\mathrm{k}+3} \\
& \text { a. člověk uctivý (sám) } k \text { sobě } \\
& \text { man respectful (alone) to } \mathrm{REFL}_{\text {long.dat }} \text {, } \\
& \text { 'a man respectful to herself/himself' }
\end{aligned}
$$

b. Člověk je uctivý (sám) $k$ sobě. man is respectful (alone) to REFL $L_{\text {long.dat }}$ 'A man is respectful to herself/himself.'

Reflexivity in Surface Structures. Surface positions provided by coreferring valency complementations of a predicate are indicated in the valency frames of the given predicate by morphemic forms. One of these surface position is occupied by the reflexive pronoun while the other is filled with its antecedent. ${ }^{10}$

The reflexive pronoun can occupy various surface positions, direct or indirect objects (with verbs), attributes (with nouns) and adverbials (with verbs and adjectives). Predominantly, it has the long form, the clitic form of the reflexive pronoun is available only with verbs in the prepositionless dative or accusative

\footnotetext{
${ }^{7}$ The valency structure of deverbal nouns typically corresponds to the valency structure of their base verbs, see esp. (Kolářová, 2014). In case of primary nouns, valency of verbs with similar meanings should be taken into account, e.g., láska 'love' and milovat 'to love', see esp. (Piha, 1984).

${ }^{8}$ For specific valency properties of adjectives in Czech see esp. (Panevová, 1998; Panevová et al., 2014).

${ }^{9}$ With deadjectival nouns, one valency complementation - typically ACT - is added to their valency frames that corresponds to the governor of their base adjectives or to ACT in constructions with copula verbs; compare, e.g., the valency frame of

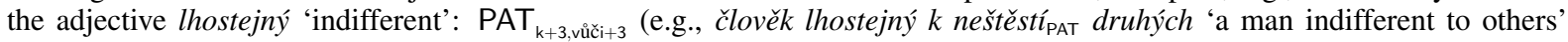

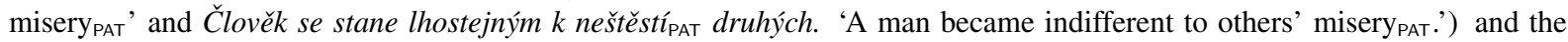
frame of the noun lhostejnost 'indifference' derived from this adjective: $\mathrm{ACT}_{2 . \text { pos }} \mathrm{PAT}_{\mathrm{k}+3 \mathrm{v} \text { vǐ́i+3 }}$ (e.g., lhostejnost člověka $a_{\mathrm{ACT}} k$ druhým $_{\mathrm{PAT}}$ 'man's $\mathrm{S}_{\mathrm{ACT}}$ indifference to others ${ }_{\mathrm{PAT}}$ ').

${ }^{10}$ Further, reflexivity can be optionally emphasized by the expression sám 'alone', see examples in (11) and (15).
} 

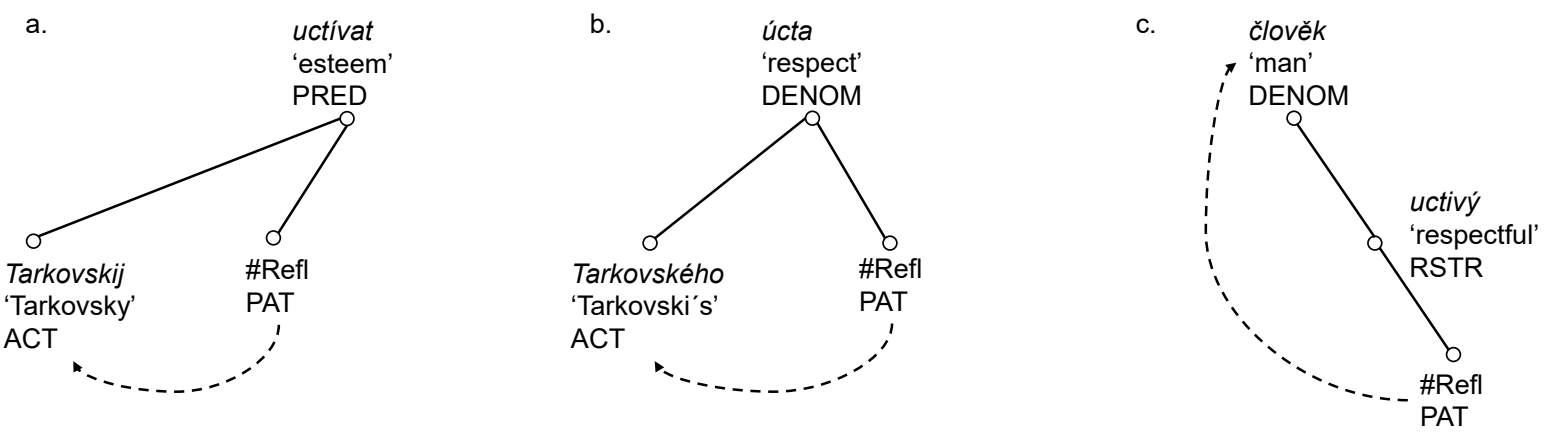

Figure 2: The simplified tectogrammatical trees of examples (11b), (13) and (15a), respectively; the dashed arrow shows coreference.

case, depending on whether it is stressed, or not, compare examples (11a) and (11b). With nouns and adjectives, the clitic forms are not available, ${ }^{11}$ only the long forms of the reflexive pronoun are acceptable (Dvořak, 2017).

As for the antecedent of the reflexive pronoun, with verbs, it is represented by subject provided by the valency complementation in nominative, typically ACT, see examples with the verb uctivat / uctit 'to respect' (11a-b) and its valency frame in (10). With deverbal nouns, the antecedent occupies the attribute position corresponding to subject of their respective base verbs; see the valency frame of the deverbal noun úcta 'respect' in (12) and example (13). With adjectives, the antecedent occupies the position of their governors or ACT of copula verbs, being thus external to adjectival structures, see examples (15a-b) with the adjective uctivý 'respectful' and its valency frame (14).

\section{Reciprocity and Its Encoding in Czech}

Reciprocity is understood here as language means expressing a semantic relation of mutuality. In Czech linguistics, reciprocity has not attracted much attention yet; even in summarizing grammars, it is mentioned only marginally, see esp. (Daneš et al., 1987; Grepl and Karlík, 1998). The most elaborated analysis of reciprocity in Czech is provided within FGD, see (Panevová, 1999; Panevová and Mikulová, 2007), being partially reflected in the Prague Dependency Treebank annotation scenario (henceforth PDT) (Hajič et al., 2018).

Reciprocity is characterized by the fact that two (or sporadically three) semantic participants of the situation denoted by a predicate are involved in a mutual relation and this mutual relation is linguistically structured within a single predicate structure. In Czech, verbs (16a), nouns (16b), adjectives (16c), and adverbs (16d) can function as reciprocal predicates (reciprocity of adverbs are left aside here as language data allowing for their analysis are too sparse).

(16) a. Petr a Pavel se / sebe (vzájemně) střídali ve vyprávění.

'Peter and Paul changed each other in talking.'

b. obava prátel o sebe (navzájem)

'friends' fear for each other'

c. lhostejní $k$ sobě navzájem 'indifferent to each other'

d. daleko od sebe 'far from each other'

Within reciprocal predicates, two groups can be distinguished: lexical and syntactic reciprocal predicates. The former group of reciprocal predicates is limited in Czech; these predicates comprise the semantic trait of mutuality in their lexical meaning (e.g., debatovat 'to debate', dohodnout se 'to agree').

\footnotetext{
${ }^{11}$ The only exception is represented by verbal nouns systematically derived from verbs.
} 
In contrast, the latter one is broader; it includes predicates that - despite not having the trait of mutuality - allow some of their participants to enter into this relation (e,g., děkovat 'to thank', budit 'to wake up $\left.\mathrm{sb}^{\prime}\right){ }^{12}$

For expressing mutuality, syntactic reciprocal predicates make use of the morphosyntactic operation of reciprocalization, applied to their valency frames. ${ }^{13}$ This operation can be applied to lexical reciprocal predicates as well, serving, however, a different function: it allows to make the affected semantic participants equal with respect to their participation in the event expressed by a predicate, see esp. (Gleitman et al., 1996).

Similarly as for reflexivity, see Section 3, the applicability of the operation of reciprocalization should be described in the lexicon, as it cannot be determined only on the basis of the valency structure of predicates, while the operation itself is regular enough to be described by rules contained in the grammar.

Reciprocity in Deep Structures. In the deep syntactic structure of reciprocal constructions, the number and type of valency complementations of a predicate are preserved. However, the mapping of semantic participants onto valency complementations is changed: two semantic participants, which - in contrast to reflexivity - refer to distinct referents, are symmetrically mapped onto valency complementations. This complex mapping is then reflected as a coreferential link between the valency complementations involved in reciprocity.
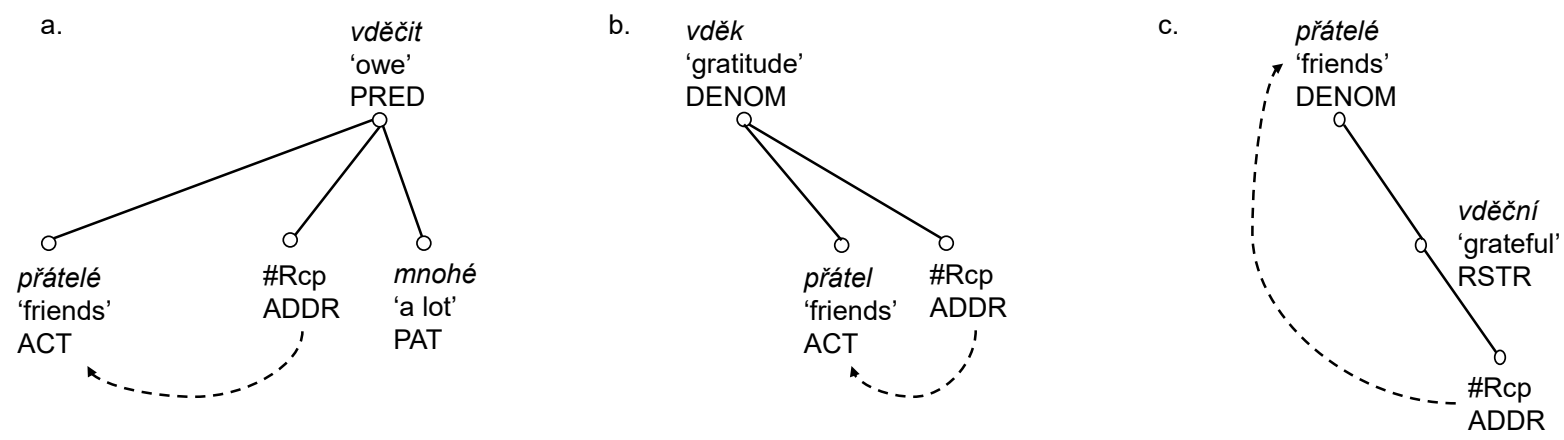

Figure 3: The simplified tectogrammatical trees of examples (18), (20) and (22a), respectively; the dashed arrow shows coreference.

Let us demonstrate the complex mapping of semantic participants onto valency complementations on the syntactic reciprocal predicates from the same derivational family, the verb vděčit 'to owe, to be grateful', the noun vděk 'gratitude', and the adjective $v d e ̌ c n y ́$ ' 'grateful'. All these predicates evoke three semantic participants: 'Experiencer', 'Addressee', and 'Reason'. With the verb and the noun, these participants are mapped onto their ACT, ADDR, and PAT, respectively, see the valency frames in (17) and (19). In contrast, with the adjective, only 'Addressee' and 'Reason' can be syntactically structured as its ADDR and PAT, respectively, see the valency frame in (21); 'Experiencer' occurs in the deep structure either as the governor of the adjective, or as ACT of the copula verbs byt 'to be' and stávat se / stát se 'to become' with the adjective (see Section 3 as well).

With these three predicates, participants 'Experiencer' and 'Addressee' can be involved in reciprocity.

\footnotetext{
${ }^{12}$ In the VALLEX lexicon, there are 241 lexical units of verbs (represented by 319 verb lemmas) indicated as lexical reciprocal verbs. In addition, 1.687 lexical units of verbs are classified there as syntactic reciprocal verbs (http://quest.ms.mff.cuni.cz/vallex/). In PDT, however, a vast majority of annotated reciprocal constructions of verbs is formed by lexical reciprocal verbs (411 instances of lexical reciprocal verbs, represented by 133 verb lemmas, out of the overall 439 instances); only in 28 instances, syntactic reciprocal verbs occur, represented by 35 verb lemmas; however, in the manual analysis of reflexive constructions in PDT (see footnote 4), it occurred that 58 other instances of verbal reciprocal structures (49 syntactic reciprocals and 9 lexical reciprocals) were incorrectly annotated as reflexive constructions. In VALLEX, data for nouns and adjectives are not available; in PDT, 558 instances of reciprocity with nouns and 2 instances of reciprocity with adjectives are annotated (plus 7 instances of lexical reciprocity with adjectives were incorrectly annotated as reflexivity). In both data resources, only those cases were counted where reciprocity affects actants.

${ }^{13}$ Conditions of its applicability (esp. semantic homogeneity of semantic participants and their same status with respect to topic-focus articulation) have been described in (Panevová, 1999).
} 
In such a case, with the verb and the noun, both 'Experiencer' and 'Addressee' are mapped onto ACT and at the same time onto ADDR, see the scheme of this mapping in Figure 4, examples (18) and (20) and their simplified dependency trees in Figure $3 a$ and $3 b$; with the adjective, the complex mapping involves ADDR from the valency frame of the adjective and either the governor of the adjective, or ACT of the copula verbs byt 'to be' and stávat se / stát se 'to become' with the given adjective, see the scheme in Figure 4, examples (22a-b) and the simplified tree of example (22a) in Figure 3c.

(17) $v$ děčit impf 'to owe, to be grateful': $\mathrm{ACT}_{\text {nom }} \mathrm{ADDR}_{\mathrm{dat}} \mathrm{PAT}_{\text {za acc,dcc }}$

(18) Prátelé / Němci a Češi si Isobě (vzájemně) vděčili za mnohé.

friends / Germans and Czechs $\mathrm{REFL}_{\text {clitic.dat }}$ / $\mathrm{REFL}_{\text {long.dat }}$ (mutually) owed for a lot

'Friends / Germans and Czechs owed each other a lot.'

(19) vděk 'gratitude': $\mathrm{ACT}_{\text {gen,pos }} \mathrm{ADDR}_{\text {dat, } k \text { dat, vǔ̌iitdat }} \mathrm{PAT}_{\text {za +acc,dcc }}$

(20) vděk prátel $k$ sobě (navzájem)

gratitude of friends to $\mathrm{REFL}_{\text {long.dat }}$ (mutually)

'gratitude of friends to each other'

vděčný 'grateful': $\mathrm{ADDR}_{\mathrm{dat}, \mathrm{v} \text { ǔiitat }} \mathrm{PAT}_{\text {za+acc,dcc }}$

(22) a. prátelé vděční sobě (navzájem)

friends grateful $\mathrm{REFL}_{\text {long.dat }}$ (mutually)

'friends grateful to each other'

b. Prátelé jsou si / sobě (navzájem) vděční.

friends are $\mathrm{REFL}_{\text {clitic.dat }} / \mathrm{REFL}_{\text {long.dat }}$ (mutually) grateful

'Friends are grateful to each other.'
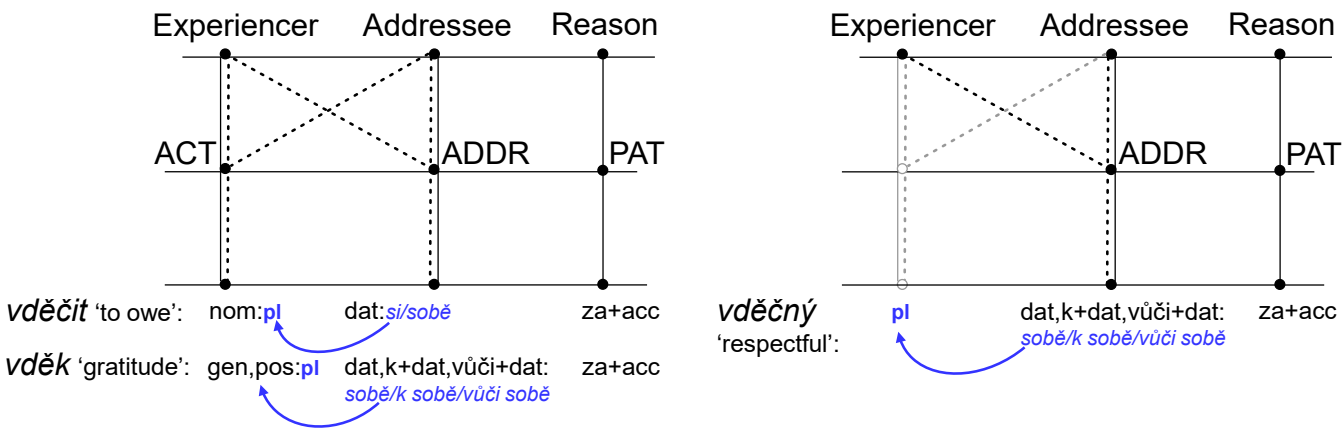

Figure 4: The scheme of the mapping of semantic participants of the verb vděcit 'to owe, to be grateful', the noun $v d e \check{k}$ 'gratitude', and the adjective $v d e \check{c} n y$ 'grateful' onto valency complementations and surface positions (the solid line depicts unreciprocal structures, the dashed line illustrates reciprocal structures).

Reciprocity in Surface Structures. With reciprocal verbs and nouns, the operation of reciprocalization involves two surface syntactic positions provided by the reciprocalized valency complementations. With reciprocal adjectives, only one surface position provided by the adjectival complementation is available; the second position is typically outside the adjectival structure, given by the governor of adjectives or by ACT of copula verbs. ${ }^{14}$

The syntactically more prominent surface position is pluralized; it can be filled with plural nouns, coordination, see example (18), and collective nouns (e.g., třída 'class', družstvo 'team', posádka 'crew'). With verbs, the more prominent position is mostly the position of subject, less frequently the position of

\footnotetext{
${ }^{14}$ Reciprocity can be optionally emphasized by adverbial modifiers navzájem, vzájemně 'mutually'; in specific cases, the modifiers spolu 'together' or mezi sebou 'between each other' can be used as well.
} 
direct object. ${ }^{15}$ With nouns, it is represented by the attribute position corresponding to the subject (or direct object) position with their base verbs. With adjectives, the more prominent position is the surface position external to adjectival structure.

For example, with the verb vděčit 'to owe, to be grateful' and the noun vděk 'gratitude', with which $A C T$ and ADDR are involved in reciprocity, the pluralized more prominent position is given by ACT; this ACT contributes subject to the verbal structure, see example (18), and the corresponding attribute position to the nominal structure (20). In contrast, with the adjective vděcny 'grateful', the pluralized position is outside the adjectival structure; typically the governor of the adjective or ACT of a copula verb are pluralized, examples (22a-b).

The less prominent surface position is either deleted from the surface, or if expressed, it can be filled with the reflexive pronoun, or with the expression jeden druhy 'each other', both coreferential with the expression in the more prominent position. ${ }^{16}$

The surface expression of the less prominent position is primarily conditioned by (i) morphemic forms of the valency complementation providing the given position and by (ii) a part-of speech of a reciprocal predicate. First, if the valency complementation has the prepositional form $s+\operatorname{Instr}$, it is systematically deleted from the surface, regardless of the part-of-speech of its governor; see the valency frame and example of the verb citit 'to sympathize' (23), the frame and the example of the noun soucit 'sympathy' (24), and the frame and the example of the adjective soucitny 'sympathetic' (25).
a. cítit impf 'to sympathize': $\mathrm{ACT}_{\text {nom }} \mathrm{PAT}_{\text {stinstr }}$
b. Lidé spolu v těžkých dobách více cítili. people together in difficult times more sympathized
'People sympathized more with each other in difficult times.'

a. soucit 'sympathy': $A C T_{\text {gen,pos }} P A T_{k+d a t, n a d+\text { tinstr,stinstr }}$

b. vzájemnýsoucit lidí $k$ sobě / nad sebou mutual sympathy of people to $\mathrm{REFL}_{\text {long.dat }}$ / over $\mathrm{REFL}_{\text {long.instr }}$ 'mutual sympathy of people'

a. soucitný 'sympathetic': PAT

b. lidé soucitní $k$ sobě / nad sebou navzájem people sympathetic to $\mathrm{REFL}_{\text {long.dat }}$ / over $\mathrm{REFL}_{\text {long.instr }}$ mutually 'people sympathetic with each other'

Second, if the valency complementation providing the less prominent position has the form of the prepositionless dative or accusative, it can have either the clitic form, or the long form, depending on its position in a sentence and a part of speech of the predicate; with verbs, both forms are available, see example (18), while with nouns and adjectives, only the long forms of the reflexive pronoun are possible, see esp. (Dvořak, 2017). ${ }^{17}$

Last, if the valency complementation giving the less prominent position has other forms than the prepositionless dative or accusative, only the long forms of the reflexive are available, see examples (20), (24b), (25b).

\section{Conclusion}

In this paper, we have addressed reflexives in Czech, with an emphasis on the reflexive pronoun. We have proposed their analysis in the Functional Generative Description, supported by data provided in the

\footnotetext{
${ }^{15}$ In Czech, the direct object position as the more prominent one is mostly involved in reciprocalization with lexical reciprocal verbs. For example, with the lexical reciprocal verb spojovat/spojit 'to combine' with the valency frame $\mathrm{ACT}_{\text {nom }} \mathrm{ADDR}_{\text {s+instr }}$ $\mathrm{PAT}_{\text {acc }}$ EFF $_{\text {do+gen,v+acc }}$, reciprocalization affects ADDR and PAT, the more prominent position thus being represented by direct object, provided by the accusative PAT (e.g., Hra spojuje rysy $y_{\mathrm{PAT}}$ komiky a horroru. 'The play combines comedian and horror

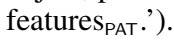

${ }^{16}$ The expression jeden druhý 'each other', which unambiguously marks reciprocity, is not discussed here (Kettnerová and Lopatková, 2018a).

${ }^{17}$ In constructions with copula verbs, the clitic form of the reflexive pronoun can occur with adjectives as well, see example (22b). However, these constructions require further attention.
} 
VALLEX lexicon and in the syntactically annotated Prague Depencency Treebank. We stress the fact that for their adequate representation both components of the language description - the lexicon and the grammar - must be taken into account.

To conclude, our in-depth analysis of deep and surface syntactic properties of Czech reflexive and reciprocal constructions allows us to explicitly formulate the conditions underlying ambiguity between reflexivity and reciprocity, which - to our best knowledge - have not been described yet: (i) the same pair of valency complementations must be affected by reflexivity and reciprocity with a single predicate (as a result, an identical pair of valency complementations are linked by coreference), (ii) the more prominent surface position is represented by the syntactic subject (and the corresponding positions with nouns and adjectives), and (iii) the antecedent of the reflexive pronoun is plural.

\section{Acknowledgements}

The research reported in this paper has been supported by the Czech Science Foundation (GAČR), grant No. 18-03984S Between Reciprocity and Reflexivity: The Case of Czech Reciprocal Constructions and partially also by the LINDAT/CLARIN project No. LM2015071.

This work has been using language resources stored and distributed by the LINDAT-CLARIN project of the Ministry of Education, Youth and Sports of the Czech Republic, project No. LM2015071.

\section{References}

Igor Boguslavsky. 2003. On the Passive and Discontinuous Valency Slots. In Proceedings of the 1st International Conference on Meaning-Text Theory, pages 129-138, Paris. École Normale Supérieure.

Noam Chomsky. 1981. Lectures on Government and Binding. Foris, Dordrecht.

František Daneš, Miroslav Grepl, and Zdeněk Hlavsa, editors. 1987. Mluvnice češtiny 3. Academia, Praha.

Mojmír Dočekal. 2008. Vázané proměnné v češtině. Ph.D. thesis, Masaryk University, Faculty of Arts, Brno.

Věra Dvořak. 2017. Dějové substantivum. In Petr Karlík, Marek Nekula, and Jana Pleskalová, editors, Nový encyklopedický slovník češtiny. Nakladatelství Lidové noviny, Praha.

Nicholas Evans, Alice Gaby, Stephen C. Levinson, and Asifa Majid, editors. 2011. Reciprocals and Semantic Typology, volume 98 of Typological Studies in Language. John Benjamins Publishing Company, Amsterdam/Philadelphia.

Leonard M. Faltz. 1985. Reflexivization: a study in universal syntax. Garland Publishing, New York.

Zygmunt Frajzyngier and Traci Walker, editors. 2000a. Reciprocals. Forms and Functions, volume 41 of Typological Studies in Language. John Benjamins, AmsterdamPhiladelphia.

Zygmunt Frajzyngier and Traci Walker, editors. 2000b. Reflexives. Forms and Functions, volume 40 of Typological Studies in Language. John Benjamins, AmsterdamPhiladelphia.

Emma Geniušienè. 1987. The typology of reflexives. Mouton de Gruyter, Berlin-New York-Amsterdam.

L. R. Gleitman, H. Gleitman, C. Miller, and R. Ostrin. 1996. Similar, and similar concepts. Cognition, 58:321376.

Miroslav Grepl and Petr Karlík. 1998. Skladba češtiny. Votobia, Olomouc.

Jan Hajič, Eduard Bejček, Alevtina Bémová, Eva Buráňová, Eva Hajičová, Jiří Havelka, Petr Homola, Jiří Kárník, Václava Kettnerová, Natalia Klyueva, Veronika Kolářová, Lucie Kučová, Markéta Lopatková, Marie Mikulová, Jiří Mírovský, Anna Nedoluzhko, Petr Pajas, Jarmila Panevová, Lucie Poláková, Magdaléna Rysová, Petr Sgall, Johanka Spoustová, Pavel Straňák, Pavlína Synková, Magda Ševčíková, Jan Štěpánek, Zdeňka Urešová, Barbora Vidová Hladká, Daniel Zeman, Šárka Zikánová, and Zdeněk Žabokrtský. 2018. Prague dependency treebank 3.5. (Dostupné z http://ufal .mff . cuni.cz/pdt3.5.).

Bohuslav Havránek. 1928. Genera verbi v slovanských jazycích I. Nová r̆ada (VIII). Kr. česká spol. nauk, Praha.

Andrea Hudousková. 2009. Dvě funkce klitiky se: různé, a přeci stejné. Slovo a slovesnost, 70(4):295-304. 
Petr Karlík. 1999. Reflexiva v češtině. In E. Rusínová, editor, Přednášky a besedy z 32. běhu Letní školy slovanských studií, pages 44-52. Filozofická fakulta Masarykovy univerzity, Brno.

Suzanne Kemmer. 1993. The Middle Voice. John Benjamins, Amsterdam-Philadelphia.

Václava Kettnerová and Markéta Lopatková. 2018a. Lexicographic Potential of the Syntactic Properties of Verbs: The Case of Reciprocity in Czech. In XVIII EURALEX International Congress, Lexicography in Global Contexts, pages 685-698, Ljubljana. Ljubljana University Press, Faculty of Arts.

Václava Kettnerová and Markéta Lopatková. 2018b. Mezi reflexivitou a reciprocitou: Poznámky k reflexivním a recipročním konstrukcím vybraných českých sloves. Prace Filologiczne, LXXII:131-145.

Václava Kettnerová, Markéta Lopatková, and Jarmila Panevová. 2014. An interplay between valency information and reflexivity. The Prague Bulletin of Mathematical Linguistics, 102:105-126.

Veronika Kolářová. 2014. Special valency behavior of Czech deverbal nouns. In Olga Spevak, editor, Noun Valency, pages 19-60. John Benjamins, Amsterdam.

Miroslav Komárek, Jan Kořenský, Jan Petr, and Jarmila Veselková, editors. 1986. Mluvnice češtiny 2. Academia, Praha.

Miroslav Komárek. 2001. Několik poznámek k reflexi reflexivity reflexiv. Slovo a slovesnost, 62(3):207-209.

Ekkehard König and Volker Gast, editors. 2008. Reciprocals and Reflexives: Theoretical and Typological Explorations. Mouton de Gruyter, Berlin.

Ekkerhard König and Shigehiro Kokutani. 2006. Towards a typology of reciprocal constructions: Focus on German and Japanese. Linguistics, 44:271-302.

Markéta Lopatková, Václava Kettnerová, Eduard Bejček, Anna Vernerová, and Zdeněk Žabokrtský. 2016. Valenční slovník českých sloves VALLEX. Karolinum, Praha.

Lucie Medová. 2009. Reflexive Clitics in the Slavic and Romance Languages. A Comparative View from an Antipassive Perspective. Ph.D. thesis, Princeton University, Princeton, NJ, USA.

Igor A. Mel’čuk. 2004. Actants in Semantics and Syntax I. Linguistics, 42(1):1-66.

Marie Mikulová, Alevtina Bémová, Jan Haji, Eva Hajiová, Jií Havelka, Veronika Koláová, Lucie Kuová, Markéta Lopatková, Petr Pajas, Jarmila Panevová, Magda Razímová, Petr Sgall, Jan tpánek, Zdeka Ureová, Kateina Veselá, and Zdenk abokrtský. 2006. Annotation on the tectogrammatical level in the Prague Dependency Treebank. Annotation manual. ÚFAL MFF UK, Prague, Czech Rep.

Vladimir P. Nedjalkov, editor. 2007. Reciprocal Constructions. John Benjamins, Amsterdam-Philadelphia.

Karel Oliva. 2000. Hovory k sobě/si/sebe/se. In Zdeňka Hladká and Petr Karlík, editors, Čeština univerzália a specifika. 2. Sborník z konference ve Šlapanicích u Brna 17.-19.11.1999, pages 161-171, Brno. Masarykova univerzita.

Karel Oliva. 2001. Reflexe reflexivity reflexiv. Slovo a slovesnost, 62(3):200-207.

Jarmila Panevová and Marie Mikulová. 2007. On reciprocity. The Prague Bulletin of Mathematical Linguistics, $87: 27-40$.

Jarmila Panevová, Eva Hajičová, Václava Kettnerová, Markéta Lopatková, Marie Mikulová, and Magda Ševčíková. 2014. Mluvnice současné češtiny 2, Syntax na základě anotovaného korpusu. Karolinum, Praha.

Jarmila Panevová. 1998. Ještě k teorii valence. Slovo a slovesnost, 59(1):1-14.

Jarmila Panevová. 1999. Česká reciproční zájmena a slovesná valence. Slovo a slovesnost, 60(4):269-275.

Jarmila Panevová. 2001. Problémy reflexivního zájmena v češtině. In Přednášky z XLIV. běhu Letní školy slovanských studií, pages 81-88. UK v Praze, FF, Praha.

Jarmila Panevová. 2008. Problémy se slovanským reflexivem. Slavia, 77(1-3):153-163.

Petr Piha. 1984. Case frames of nouns. In Petr Sgall, editor, Contributions to Functional Syntax, Semantics, and Language Comprehension, volume 16 of Linguistic and Literary Studies in Eastern Europe, pages 225-238. John Benjamins, Amsterdam. 
Carl Pollard and Ivan A. Sag. 1992. Anaphors in English and the scope of binding theory. Linguistic Inquiry, 23(2):261-303.

Tanya Reinhart and Eric Reuland. 1993. Reflexivity. Linguistic Inquiry, 24:657-720.

Petr Sgall, Eva Hajičová, and Jarmila Panevová. 1986. The Meaning of the Sentence in Its Semantic and Pragmatic Aspects. Reidel, Dordrecht.

Vojtěch Veselý. 2018. K slovotvorné funkci reflexivních morfémů se, si. Naše řě̌, 101(3):138-157. 